Editorial

\title{
Leaving the Quiet Jungle Path: Introduction to Maya Anthropological Archaeology
}

\author{
Chelsea Fisher ${ }^{1}$ and Arlen F. Chase ${ }^{2, *(D)}$ \\ 1 Environmental Studies Program, Washington and Lee University, 018 Tucker Hall, Lexington, VA 24450, USA; \\ cfisher@wlu.edu \\ 2 Department of Anthropology, Pomona College, 420 N. Harvard Ave., Claremont, CA 91711, USA \\ * Correspondence: arlen.chase@pomona.edu
}

Citation: Fisher, C.; Chase, A.F. Leaving the Quiet Jungle Path: Introduction to Maya Anthropological Archaeology. Heritage 2021, 4, 979-984. https://doi.org/10.3390/ heritage 4020053

Received: 5 June 2021

Accepted: 9 June 2021

Published: 11 June 2021

Publisher's Note: MDPI stays neutral with regard to jurisdictional claims in published maps and institutional affiliations.

Copyright: (c) 2021 by the authors. Licensee MDPI, Basel, Switzerland. This article is an open access article distributed under the terms and conditions of the Creative Commons Attribution (CC BY) license (https:// creativecommons.org/licenses/by/ $4.0 /)$.
In her book Maya Cultural Heritage: How Archaeologists and Indigenous Communities Engage the Past (Roman and Littlefield 2016), Patricia McAnany urges archaeologists who work in the Maya region (i.e., southern Mexico, Guatemala, Belize, western El Salvador, and western Honduras) "to leave the quiet jungle path" (p. 6) - that is, the mindset where many archaeologists comfortably assert exclusive mastery of the past- "and engage with an archaeological practice that is more uncertain but more inclusive". This place of uncertainty and inclusivity to which McAnany and others steer us is the busy, often fraught, intersectional space of cultural heritage, where multiple and diverse sorts of people command simultaneous and often competing claims to the past.

As more archaeologists working in the Maya region enter this intersection, we are seeing in real time an archaeology that willfully and thoughtfully engages with cultural heritage to better preserve the past, while at the same time yielding new forms of knowledge. Aside from enriching research efforts, archaeological engagement with Maya cultural heritage has proven itself a capable vehicle for social and environmental advances. In addition, heritage programs implemented throughout the Maya region are showing how equitable partnerships with local communities and governments move archaeological research forward, while also contributing tangible benefits on the ground. Collaborative, engaged, and community-based archaeologies offer actionable practices to enfranchise multiple voices, center Indigenous ways of knowing, and work towards decolonizing the discipline. Yet, even with all of these positive reasons that Maya archaeologists should move into the spaces of cultural heritage, relatively few are actually making such movesand understandably so; while conceptually the case for engaging with cultural heritage may be easy, the on-the-ground employment of such practices is unpredictable, chaotic, and often difficult.

When we issued the call for papers that ultimately led to this collection, we aimed to compile an open-access repository of "on-the-ground" narratives from Maya archaeologists who have positioned themselves, their projects, and their practices within larger discussions of cultural heritage. The assembled collection of articles hopefully both increases the visibility of these endeavors and embraces a frank discussion of the positives and negatives of actual practice, offering a gestalt model of the ground-level efficacy and experience of heritage-oriented archaeology in the Maya region. Rather than focus on the products of their work, we encouraged contributors to emphasize the process-the logistics, the practicalities, and the nitty-gritty - that played out on the ground. How did these approaches spawn new research questions? How did they impact knowledge production? What challenges arose? How were they managed? Additionally, how were practices prevented from entering a neo-colonialist realm?

By contextualizing research alongside a candid and transparent discussion of the surprises, improvisations, and setbacks met along the way, the contributors in this collective enterprise co-create a widely accessible resource meant to catalyze further archaeological 
engagement with cultural heritage work within the Maya region, as well as to provide examples and lessons that may prove to be useful globally. With this spirit, we invited contributions dealing with a range of topics that we were interested in exploring, including but not limited to the following:

Building and sustaining mutually beneficial partnerships with local and Indigenous communities and governments at all levels;

Local heritage tourism at archaeological sites;

Globalized heritage tourism (i.e., UNESCO World Heritage sites) in the Maya region; Collaborative protection and conservation of archaeological resources with communities and governments;

Navigating partnerships with non-profits and for-profits;

Measuring the mutual benefits and, in some cases, contra-positives of community partnerships over time;

Collaboratively designing heritage programs for social and environmental goals;

Modes of cultural heritage programs (e.g., educational activities, workshops, radio shows, cooking demos, and community mapping);

Development of local cultural heritage centers (e.g., local museums) by and with communities; and,

Ensuring that foreign and non-local researchers are not neo-colonialists in their approaches to cultural heritage.

We received manuscripts for thirteen full-length articles in response to our call for papers. Perhaps among the most salient themes to emerge from the submissions, briefly summarized below, is that context, positionality, and reflection matter a great deal in heritage-oriented archaeological projects. With that in mind, we offer this context: the papers in this collection were written or revised during the early days of the COVID-19 pandemic. Those were months of great uncertainty and perhaps that uncertainty shades the perspectives offered here. These papers co-create a repository of reflections and narratives of a more uncertain archaeological practice-forays off the "quiet jungle path" — gathered during a more uncertain time and offered towards a more uncertain future.

The thirteen papers collected in this volume include accounts of heritage-oriented archaeological projects from across Belize, Guatemala, and Mexico. We summarize them here in the order they are presented, making thematic connections where possible. We follow these summaries by distilling four key takeaways for future work: (1) focus on process; (2) prepare to address actual, not assumed, community needs; (3) engage in proactive and practical steps to decolonize archaeological practices; and (4) actively address our positionality within local dynamics.

In Patricia McAnany's [1] contribution to this collection, she invites us to imagine a Maya archaeology that is both truly anthropological and concurrent with Indigenous heritage concerns. To get there, she says, we have to embrace the fact that archaeological practice and cultural heritage are distinct. Each offers a different, at times contradictory, paradigm for interacting with the past. However, when archaeological practice and cultural heritage are held in productive tension, these "restless bedfellows" together render possible a Maya archaeology that decolonizes its methodologies, enfranchises local communities, and sustains itself into the future.

Two of the papers included here reflect on multi-decade archaeological research and conservation efforts in Belize. First, in the Belize Valley, Hoggarth and her colleagues detail a history of research and community involvement. Second, at the massive site of Caracol, Chase and his colleagues detail a long-term collaborative project that served both research and cultural heritage objectives. In both articles, the archaeologists share how partnerships with the Belize government allowed them to undertake an ambitious program of excavation, conservation, and tourism development. Early initiatives also fostered project cultures oriented towards developing Belize's capacity to steward its own heritage. As shown by these long-term projects, archaeology in the last half century has moved from "basic research to one where research has become intertwined with tourism 
and economic benefits that accrue therein" [2] (p. 451) and is now engaged in "training the next generation of archaeologists, heritage managers, and tour guides", making sure "that local perspectives and knowledge are infused into public archaeology in the future" [3] (p. 720).

At the fringes of mainstream and government-sponsored tourism, community-led alternative tourism programs also offer fruitful ground for collaborative heritage work. Ecotourism is a thriving industry in Quintana Roo, thanks in no small part to the cluster of luxury resorts and tourist amenities concentrated along the Riviera Maya. In contrast to enormously popular ecotourism attractions such as Xcaret, a privately owned Maya site and theme park, grassroots ecotourism ventures can create sustainable and direct benefits for Indigenous Maya communities such as Punta Laguna, as documented by Sarah Kurnick. In the Indigenous Maya community of Yaxunah, Yucatán, another kind of alternative tourism-culinary tourism-mingles with heritage politics and archaeological practice. Chelsea Fisher and Traci Ardren relate how globalization has impacted the heritage of a local community by relating how in 2017 a world-renowned celebrity chef hired tortillamakers and sourced local produce from the community for a high-end pop-up restaurant in Tulum, specifically examining how "neoliberalism and so-called sustainable development" are "inextricably linked" [4] (p.489) with presumably unintended consequences. The community's involvement with the pop-up restaurant transformed the local food landscape that spring - and continues to reverberate globally through a recent Netflix special and an influx of "foodie" tourism, even during the pandemic.

As attention to long-term histories of human-environment interactions continues to grow in the Maya area, partnerships centering environmental heritage offer another template for community-engaged archaeology. Cynthia Ellis Topsey, Anabel Ford, and Sherman Horn III mobilize their "different ways of knowing" to share insights gleaned from their work with the El Pilar Archaeological Reserve for Maya Flora and Fauna, an associated Welcome Center in the nearby town of Cayo, and active educational gardens in both urban and rural settings. Belize's landscape is constantly transforming through deep human relationships with the forest, and "from the diversity of Belizean heritage," the authors say, "a global forest garden emerges with different sources of knowledge generating a vital base for health and well-being" [5] (p. 508).

Archaeologists working in the Maya area tend to assume that local communities will connect with pre-Contact Maya culture as their heritage, but that assumption is often misguided. Many communities more readily identify with the heritage of recent historical events. Through their work in Tihosuco, Mexico, Diserens Morgan and Leventhal discuss the ways that their community heritage project has evolved in flexible response to changing perceptions of heritage within the Tihosuco community; through these reflections, the authors share how their collaborative project is "working to create a kind of heritage engagement in the region that centers on people's relationships with anti-colonial movements, such as the Caste War, while also promoting small-scale economic projects and future cultural development" [6] (p. 516).

Mario Zimmermann and his colleagues address similar dynamics at the ex-hacienda San Pedro Cholul in Yucatán, where the heritage of the state's Gilded Age (ca. 1860-1915) may resonate more strongly with present interests than pre-Contact history; they show how archaeology and collaboration empowered the descendent community to assert their own perspectives on the region's cultural heritage. Likewise, while many communities in the Maya archaeological area identify as ethnically Maya, many do not. In Belize, the national heritage discourse emphasizes the pre-Contact Maya, while Creole people-who trace their ancestry to Europeans and enslaved Africans brought to Belize as loggers during the colonial period-are largely absent. Eleanor Harrison-Buck and Sara Clarke-Vivier examine their experiences running a Creole heritage-oriented project and community museum with the Creole community of Crooked Tree, Belize: "In heritage-oriented archaeology projects, collaboration cannot happen after the fact, and it is never peripheral to the work; it is the work" [7] (p. 430). 
Throughout this collection, authors point out that community-engaged projects must be ready to contribute towards actual community needs, even if those needs fall outside the boundaries of archaeology. This is particularly apparent in two papers from projects working in Guatemala and the southwestern Maya lowlands. Preserving cultural heritage is a priority for members of the Ceibal-Petexbatún Archaeological Project, but so too is mobilizing to improve local economic conditions in the face of land grabbing and deforestation; Jessica MacLellan, Melissa Burham, and Maria Belén Méndez Bauer recall their experiments in creating economic opportunities for a community near Ceibal called Las Pozas, pointing out that flexibility and communication are key to creating lasting economic benefits for local communities. Similarly, Brent Woodfill and Alexander Rivas contribute a chapter reflecting on the role of community-engaged archaeological projects in regions facing severe systemic problems. Indigenous communities in Guatemala and across the border in Chiapas often cannot prioritize heritage work given the precarity of provisioning even basic needs such as clean water, medicine, and farmland. Woodfill and Rivas [8] (p. 562) "believe that archaeologists better serve these communities by being a transient (for even multi-year investigations must end) toolkit to address issues and problems of their choosing" by leveraging privilege and access to advocate for communities whenever possible.

Because engaged archaeology and heritage-oriented work rely so much on interpersonal dynamics, introspection is essential. Reflection is a core theme across the articles in this collection. Scott Hutson and his colleagues show that heritage projects are shaped not just by the interests of local stakeholder groups, but also by the positionality (e.g., gender, sexuality, class status) of the archaeologists involved: "For us, part of increasing democracy was to recognize the partiality of our own perspectives and not let our habitual standpoints silently guide decisions about running an archaeology project" [9] (p. 234). Kenneth Seligson and Manuel Chi Nah offer a collection of narrative vignettes, comparing through stories their perspectives on collaborative archaeological work. The dialogue shared here is an invitation to realistic introspection for all heritage-oriented archaeologists.

A decade ago, reflecting on community-oriented archaeology in 2011 (in the book Global Public Archaeology, edited by Matsuda and Okimura for Springer), Ann Pyburn (pp. 15-16) wrote:

“(M)ost archaeologists underestimate the amount of community oriented archaeology that was done and the degree of commitment and intellectual rigor applied to public outreach before the present generation... What has always been true, and is still true to a significant extent, is that community engagement has shared the low status in academic circles of applied anthropology or sociology and in many quarters is still generally not considered to be archaeology at all. Consequently most of what has been done remains an unremarked and unpublished part of archaeology's oral history."

Later in that same essay, Pyburn listed out some of the published studies that did demonstrate archaeological engagement with heritage. Stepping back, she observed, "The accumulated wisdom of all these efforts is considerable, but the emphasis still tends to be placed on the originality of each study rather than on increasing a useful bank of knowledge" (p. 18). This collection of papers addresses Pyburn's critiques by carving out a space for candid discussion of what has, and has not, been working in our own engagements with heritage-oriented and community-based archaeology. We hope that this collection of articles becomes part of a growing "useful bank of knowledge" that anchors in the academic literature where we were and points to where we might go from our present stasis. With that in mind, we conclude our introduction to this collection with four takeaways distilled from these thirteen articles.

First, heritage-oriented archaeologists are encouraged to focus on process, not on end products. True community engagement cannot be forced, but rather unfolds when archaeological projects do the work of nurturing sustained relationships, upholding commitments, and maintaining clear and open channels of communication. Focusing on process opens 
the door for more equitable and inclusive archaeologies; when a project abandons as its top priority one-sided conceptions of efficiency, it frees up space for more intentional conversations with all stakeholders about how decisions will be made and what matters to community members. Some heritage-oriented archaeological projects began with this focus on process built in from the start; others are retrofitting it into their operations. Wherever we are as individuals across that spectrum, we need to attend not only to how our own practices can prioritize process, but also to how our academic systems (e.g., tenure and promotion; expectations for and structure of dissertation projects) can be reimagined to better support process-focused archaeology.

Second, the articles in this collection urge archaeologists to prepare themselves to address actual community needs. Community needs should not be assumed, should not be fabricated based on our own interests, and should not be regarded as staticdetermining needs should be an ongoing conversation with community members. This also means that engaged archaeologists must be ready to take on community "asks" that are not strictly archaeological (nor perhaps what we had originally envisioned when we wrote the "Broader Impacts" section of our grant applications). Attention to context is key. Did a celebrity chef suddenly start hiring locals? Do local tour guides have up-to-date training? Did farmers all just lose a harvest? Is land grabbing starting to encroach on local landholdings? Would people really rather be learning English than Maya hieroglyphs? When communities self-determine their own needs and interests, heritageoriented archaeologists must listen actively and prepare to respond in concrete ways.

The third takeaway is to engage in proactive and practical steps to decolonize archaeological practices. In her chapter, McAnany [2] (p. 322) urges heritage-oriented archaeologists "to work proactively to ensure that descendant/local communities have a right to exercise authority over decisions regarding their heritage. When archaeologists work to safeguard this process, we engage in methods otherwise known as decolonization". The Tihosuco Project is explicitly attuned to anti-colonial movements and drawing upon reflections published in AP3A (2020, Vol. 31) by Tihosuco Project member Tiffany C. Fryer (p. 27), we might step back and ask ourselves how the "members of each of the participating organizations" in a heritage-oriented project can "act jointly to advocate for and support spaces for (community members) to assert their rights to historical self-representation"? The frank discussion of efforts and experiments described in this collection offer a humbling sense of the long journey still ahead in decolonizing the discipline of archaeology.

A fourth and final takeaway for heritage-oriented archaeologists: actively address your own positionality. Honest and open communication with stakeholder groups cannot be realized without attending to our own personal contexts-race, gender, sexuality, class status, age, ability status, etc., and how they influence our archaeological practice. Introspection is part of this, but so too is dialogue and narrative.

The stories shared in this collection show that the assumptions and expectations we tacitly harbor in our personal worldviews can be detrimental to engaged archaeology, especially if not actively addressed. Sharing these narratives openly is critical to building up our "bank of knowledge" as heritage-oriented archaeologists. In most of our publications, the trajectory from research question to research conclusion is smoothed to suggest a linear and orderly progression. This veneer covers the messiness of fieldwork, logistical disasters, and mistakes, but it also conceals the positive surprises, the life-changing meetings and partings of collaborators, and the unexpected turns that lead to discovery. Open sharing of the nitty-gritty details-both the good and the bad-enables archaeologists to learn from each other and, through that co-learning, to move the discipline towards process, responsiveness, and decolonization.

Let us leave the quiet jungle path, together. 
Author Contributions: The article was co-written by both authors. All authors have read and agreed to the published version of the manuscript.

Funding: This research received no external funding.

Institutional Review Board Statement: Not applicable.

Informed Consent Statement: Not applicable.

Data Availability Statement: Not applicable.

Conflicts of Interest: The authors declare no conflict of interest.

\section{References}

1. McAnany, P.A. Imagining a Maya Archaeology That is Anthropological and Attuned to Indigenous Cultural Heritage. Heritage 2020, 3, 318-330. [CrossRef]

2. Chase, A.F.; Chase, D.Z.; Morris, J.M.; Awe, J.J.; Chase, A.S.Z. Archaeology and Heritage Management in the Maya Area: History and Practice at Caracol, Belize. Heritage 2020, 3, 436-456. [CrossRef]

3. Hoggarth, J.A.; Awe, J.J.; Ebert, C.E.; Guerra, R.A.; Beardall, A.; Watkins, T.B.; Walden, J.P. Thirty-Two Years of Integrating Archaeology and Heritage Management in Belize: A Brief History of the Belize Valley Archaeological Reconnaissance (BVAR) Project's Engagement with the Public. Heritage 2020, 3, 699-732. [CrossRef]

4. Fisher, C.; Ardren, T. Partaking in Culinary Heritage at Yaxunah, Yucatán during the 2017 Noma Mexico Pop-Up. Heritage 2020, 3 , 474-492. [CrossRef]

5. $\quad$ Ellis Topsey, C.; Ford, A.; Horn, S., III. Different Ways of Knowing and a Different Ways of Being: On a Path to Reawakening Legacy of the Maya Forest. Heritage 2020, 3, 493-510. [CrossRef]

6. Diserens Morgan, K.; Leventhal, R.M. Maya of the Past, Present, and Future: Heritage, Anthropological Archaeology, and the Study of the Caste War of Yucatan. Heritage 2020, 3, 511-527. [CrossRef]

7. Harrison-Buck, E.; Clarke-Vivier, S. Making Space for Heritage: Collaboration, Sustainability, and Education in a Creole Community Archaeology Museum in Northern Belize. Heritage 2020, 3, 412-435. [CrossRef]

8. Woodfill, B.K.S.; Rivas, A.E. Addressing Problems beyond Heritage, Patrimony, and Representation: Reflections on Twenty Years of Community Archaeology in the Southwestern Maya Lowlands. Heritage 2020, 3, 561-586. [CrossRef]

9. Hutson, S.; Lamb, C.; Vallejo-Cáliz, D.; Welch, J. Reflecting on PASUC Heritage Initiatives through Time, Positionality, and Place. Heritage 2020, 3, 228-242. [CrossRef] 